\section{Graphite Blocks for the Dounreay Reactor}

THE Morgan Crucible Co., Ltd., of Battersea, London, S.W.11, has now been permitted to reveal that for the first time special borated graphite blocks were used by the United Kingdom Atomic Energy Authority in the assembly of the shield which surrounds the reactor vessel at the Authority's experimental station at Dounreay. The blocks were made and machined by the Morgan Crucible Co., at its works at Norton, near Worcester. This factory is not engaged in the production of nuclear pure material and was therefore chosen as one suitable for handling large quantities of boron compounds. Most of the borated graphite contained 0.3 per cent boron, but some contained 5 per cent-in both cases very uniformly distributed throughout the graphite. The blocks themselves were machined to five hundred different patterns, some of which were so intricate that wooden dummies were made to ensure that it was practicable to machine them in graphite. As a final check, the layers of finished graphite blocks were assembled at Norton. The blocks, painted with distinguishing coloured bands to avoid any risk of confusion with nuclear pure material, were then packed into cartons for the journey. Transport to Dounreay was by heavy lorry, which made one round trip of 1,500 miles per week, taking the whole dry season of one year-some eight months in all.

\section{World Meteorological Organization Conferences} and Symposia, 1960

The World Meteorological Organization has issued a provisional schedule of conferences and symposia to be organized in 1960: January, Meeting on Atomic Transport and Removal of Radioactive Debris from Nuclear Tests (New York); March, Facsimile Broadcasts of the Working Group on Telecommunications, established by Regional Association VI (Offenbach-Frankfurt); April, Eastern Caribbean Committee of Regional Association IV of North and Central America (Curaçao) ; June 27July 15, Executive Committee-twelfth session; August, Working Group on Telecommunications of the Commission for Synoptic Meteorology ; August 16-September 3, Commission for Maritime Meteorology-third session (Utrecht); September-October, Regional Association VI, Europe-third session (Lisbon or Madrid); South American Regional Seminar on Tropical Agrometeorology (Venezuela); Working Group on the Guide to Climatological Practice established by the Commission for Climatology (Geneva) ; November 21-26, Working Group on Telecommunications-established by Regional Association I, Africa-fifth session (Cairo) ; November 28December 16, Regional Association I, Africa - third session (Cairo); December 1-16, Commission for Climatology-third session (London).

\section{Recent Geophysical Work in Great Britain}

The meeting of the Geological Society of London on January 27 will take the form of a symposium on "Geological Implications of Recent Geophysical Work in the British Isles". The afternoon session will discuss "The Study of Igneous Rock Masses". The principal speakers will be Dr. M. H. P. Bott (University of Durham), who will speak on granites, crustal structure and isostasy, and Dr. D. J. Blundell (University of Birmingham), whose subject will be the use of roek magnetism in studies of igneous geology. Other contributors will be Prof. T. Murphy
(School of Cosmic Physies, Dublin) and Mr. S. H. U. Bowie (chief geologist, Atomic Energy Division, Geological Survey). The evening session will consider "The Study of Sedimentary Basins". The principal speakers at this session will be Mr. N. G. O'Halloran and Mr. R. G. W. Brunstrom (British Petroleum Co.), on the use of seismic reflexion methods in geophysical surveying, and Dr. W. Bullerwell (Geological Survey), on aeromagnetic surveys over central, eastern and southern England. Prof. W. B. R. King and Mr. G. Armstrong (chief geologist, National Coal Board) will also speak. At the close of the evening session the discussions at both sessions will be summarized and reviewed by Prof. J. H. Taylor (King's College, London).

\section{"Inadequacy of Scatter Mechanisms in Tropo- spheric Radio Propagation"}

Is a communication under this title in Nature of November 14, p. 1558, it was stated that "the lenses have an average size of a few kilometres diameter". Mr. P. C. M. de Belatini states that this should read "a few metres". The toroids themselves are believed to be on average about 600 metres in diameter with an 'eye' that acts as the lens of about 15 metres diameter. These dimensions, of course, vary with time.

\section{Announcements}

Mr. B. A. Worswick, recently chief engineer of Fischer and Porter, Ltd., has been appointed technical director with a seat on the Board of Elcontrol, Ltd. He was previously chief development engineer of Bailey Meters and Controls, Ltd., after having served for some years with Imperial Chemical Industries, Ltd.

THE International Sericultural Commission has announced that the second International Technical Sericultural Conference will be held in Murcia, Spain, during April 2-5. Further information can be obtained from A. Schank, General Secretary-founder, Commission Séricicole Internationale, Station de Recherches Séricicoles, 28 Quai Boissier de Sauvages, Alès, France.

The Brighton Technical College School of Pharnacy has announced that a course of eight evening lectures on Spectroscopic Methods of Pharmaceutical Analysis will be held during the period February 9-March 29, at the Main Hall of the College, Richmond Terrace, Brighton 7. Further details can be obtained from Dr. J. C. Parkinson, School of Pharmacy, Technical College, Brighton 7.

A CONFERENCE on the Actinomycins and their Importance in the Treatment of Tumours in Animals and Man will be held under the auspices of the New York Academy of Sciences at the Barbizon-Plaza Hotel in New York City during March 31-April 1. Further information can be obtained from the Executive Dircctor, New York Academy of Sciences, 2 East 63rd Street, New York 21, N.Y.

ERrata. In the communication entitled "A Funetional Interpretation of the Flectron-Microscopic Structure of the Sensory Hairs in the Cristre of the Elasmobranch Raja clavata in Terms of Directional Sensitivity" in Nature of December 5, p. 1807, Prof. $O$. Lowenstein points out that there are two mistakes: par. 3, line 1, for "when" read "why"; a grant acknowledged in the penultimate paragraph was from the Swedish Medical Research Council, not the Karolinska Institutet as printed. 